\title{
ECOLOGICAL AND ENVIRONMENTAL STUDY OF EUPATORIUM ADENOPHORUM SPRENGEL (BANMARA) WITH REFERENCE TO ITS GALL FORMATION IN GORKHA-LANGTANG ROUTE, NEPAL
}

\author{
K. Shrestha, E. Wilson and H. Gay
}

\begin{abstract}
Eupatorium adenophorum Sprengel is a forest killer widely spreading as weed in Nepal. A study on its ecology and utilization was carried out in central Nepal with reference to its gall formation. This banmara is attacked by Procecidochares utilis, a gall which causes metabolic and physical damage to the plant. The main field survey was done in Gorkha-Langtang area and compared with the phenomenon with that of Kathmandu Valley. It has been found that the index of exposure has no effect on the plant growth; $\mathrm{pH}$ also has no effect where as soil and gall formation has some effect on plant growth. Artemisia vulgaris and Urtica dioca were commonly found in association with Eupatorium adenophorum. Though the plant acts as forest killer, some beneficial phenomena were also recorded.
\end{abstract}

Key index: Correlation coefficient, Gall formation, index of exposure, life cycle, quadrates Introduction

Eupatorium adenophorum Sprengel, locally known as Banmara (killer of the forest), is widespread across Nepal, with an altitudinal range of $800-2000 \mathrm{~m}$, where it causes extensive damage to grazing land and natural forests. It is a perennial shrub belonging to the family Compositae. The pure white flower heads, loosely clustered on glandular pubescent stalks, are fragrant. It forms dense thickets up to $3 \mathrm{~m}$ tall, and thus exerts its damaging effects by shading out seedlings in the under storey.

E. adenophorum is an exotic weed, originally from Jamaica and Mexico. It is thought that the plant arrived in Singapore in the late nineteenth century by ship, where it may have been used as cargo packing. It subsequently spread rapidly over the whole continent by virtue of its buoyant seeds an alternative explanation for the entry of the plant into Nepal is that it was introduced into India as an ornamental, whence seeds were transported into Nepal by a locust invasion. This destructive invasive weed (Swaminathan and A. Raman, 1981) has established itself in many subtropical regions of the world, including Australia, New Zealand and Hawaii, where its biological control has been affected by the introduction of the gall forming tephritid gall fly Procecidochares utilis (Stone), native to Mexico.

In 1967, this fly was imported from Bangalore (S. India) to Assam (N.E. India) and spread into Nepal from the East. A population derived from these flies was bred by the Agricultural Research Centre at Khumaltar and released in the Kathmandu Valley in an attempt to halt the rapid spread of the weed through out the country. 
Attack on $E$. adenophorum by $P$. utilis causes heavy galling of stems. This occurs as a response of the plant to feeding by fly larvae (Hoy 1960). The life cycle of $P$. utilis lasts 45-55 days. The eggs are laid between the young paired, folded leaves at the tips of the young shoots (Rao et al. 1971). The incubation period is 4-6 days. On hatching, the creamy white larvae migrate downwards to the base of the leaves, and penetrate the meristematic tissues, causing formation of galls $1-2 \mathrm{cms}$ in diameter. The last instar larva makes a circular hole referred to as an emergence window in the wall of the gall. Pupation follows 20 days spent in the larva stage. 2-3 weeks later, the adults escape via the emergence windows. Mating and egg lying occur immediately and continue throughout the adult life of 2-3 weeks. (Wilson et al. 1985,).

The damage to the plant caused by the fly takes the form of reduced foliage and stem growth and seed production. In addition to the damage caused by the galls to the physiology of the plant, the emergence holes provide entry for micro-organisms which cause decay.

\section{Aims and Objective}

In Nepal, control of $E$. adenophorum by the gall fly appears to be less successful than in other countries. The chief aims of the expedition were to assess the extent of the fly's regulatory effect and to determine the ecological limitations responsible for any reduction in the fly's efficiency.

a) To investigate the ability of $P$. utilis to reduce the population density of the weed $E$. adenophorum and hence it's potential as a regulator of this pest in Nepal. This was studied by comparing gall density (number of galls per given area) with stem density (number of stems per given area), a positive correlation indicating a density dependent response and thus potential regulation. The number of plant stems, and galls produced on them by $P$. utilis, was assessed within a wire frame quadrat of appropriate size. Sampling was performed in Trishuli, Gorkha and Betrawati areas, where exhibited approximately constant rainfall and altitude, minimizing variables which may affect fly activity. Biased selection of sampling sites was exercised in order to encounter a range of plant densities.

b) To investigate the effect of secondary parasite activity on potential regulatory efficiency of the fly. It has been hypothesized that the secondary parasitization of $P$. utilis is responsible for its reduced effectiveness as an agent of biological control in Nepal compared to other countries (Swaminathan \& Raman, 1981). This was tested by determining the number of galls which were parasitized within the total gall population. A sample of galls was taken from each quadrat and the contents reared through to:-

1) identify secondary parasites

2) assess the proportion of parasitized galls from each sample site.

Secondary parasite abundance was correlated with gall numbers and their density dependent responses determined above in (a). 
c) To investigate the variation of fly activity with rainfall. From studies of the control of $E$. adenophorum by $P$. utilis in Hawaii, it is hypothesized that the fly is ill adapted to conditions of high moisture, and is thus less effective as an agent of biological control in areas of higher rainfall. (Dodd, A.P, 1953). The data collected for the determination of the potential regulatory efficiency of $P$. utilis from the 2 rainfall bands were compared to assess the effect of rainfall on fly activity.

\section{Materials and Methods}

The survey of the gall flies in E. adenophotum was done in Kathmandu, Gorkha. Betrawati and Langtang area in the lower altitude were E. adenophorum stands were abundant.

On encountering dense stands of $E$. adenophorum a number of criteria were employed in site selection and execution of sampling methods:-

1) A site was defined as an area of $E$. adenophorum sufficient to accommodate $1040 \mathrm{~cm}^{2}$ quadrates arranged as a transect through the clump.

2) The quadrate area was determined on the basis that it should contain $20-50$ stems and was kept constant throughout the project.

3) In selection, a potential site was examined for presence of galling, since the spread of $P$. utilis to all areas could not be assumed.

4) There was positive discrimination towards sites of easy access.

5) When recording the number of stems within a quadrat, a 'stem' was deemed to be one of a height of greater than $30 \mathrm{~cm}$, where prolific branching occurred branchlets from the main stem were counted as single stems unless they were less than $30 \mathrm{~cm}$ in length. Altogether 24 quadrates were fixed

At each site the following observations were made:-

was kept constant throughout the project.

a) The length of the selected clump of $E$. adenophorum was measured.

b) A transect was taken through each clump, placing the 10 quadrates systematically.

c) At each site the number of stems and the number of galls within each quadrate were counted in order to test for the potential regulation. Data to test for the effect of rainfall on regulation were collected from 2 different rainfall bands :

Betrawati-Trisuli to Gorkha (1500-2000mm/yr)

Kathmandu Valley (1000-1500mm/yr)

The investigation of the effect of secondary parasitization on the potential regulatory efficiency of the fly involved the rearing to maturity of gall contents to enable determination of the number of parasites per gall and hence \% of secondary parasitization. From each quadrate at sites 3-16 a sample of 6 unmerged galls was placed in an aerated plastic bag for the purpose of rearing to maturity. Where any quadrate contained less than 6 galls, the maximum number possible was obtained. The bags were kept for a period of 4 weeks (the length of the 
fly's life cycle) and a count of the number of emerged parasites and gall flies made at regular intervals. On emergence, both flies and parasites were removed from the bags and placed in collecting boxes for identification on return to England.

In addition, the following observations were made at each site:

1) General site description including a photographic record

2) Aspect, 3)Topography, including exposure measurement

3) Soil pH, color, texture and type

4) Evidence of soil erosion

5) Plant height and habitat

6) Associated flora

7) Past and present land use

The methods employed were hampered by the following:

a) There was often insufficient galling within a quadrate for large enough sample of galls for rearing through.

b) Due to monsoon conditions, dampness within the gall bags occasionally resulted in the galls and thus preventing fly emergence.

\section{Results}

Observation in Betrawati-Gorkha area

$\begin{array}{lllllll}\text { Site number } & 1 & 2 & 3 & 4 & 5 & 6 \\ \text { Total stems/site } & 209 & 150 & 326 & 228 & 187 & 312 \\ \text { Total live galls/site } & 22 & 21 & 13 & 30 & 45 & 28 \\ \text { Parasites/gall/site } & - & 0.14 & 0 & 0 & 0.34 & 0.30 \\ 1 \text { Total flies/site } & - & 3 & 0 & 7 & 14 & 12 \\ \text { Total flies/live gall } & - & 0.42 & 0 & 0.63 & 0.48 & 0.52 \\ \text { 2 Total no. flies/site } & - & 8082 & 0 & 18096 & 21061 & 14.56 \\ \text { 3 Total no. parasites } & - & 2094 & 0 & 0 & 15.3 & 8.4\end{array}$

1. Given by flies \& parasites/site.

2. Given by (flies \& parasites/live gall) \& total no. of live galls in site.

3. Given by (parasites/live gall) \& total no. of live galls in site. 
Plants found growing with Eupatorium adenophorum at the Sites

Plants were identified to genus and in some cases to species. They are grouped as herbs, trees or ferns and fern allies.

$\begin{array}{ll}\text { Herbs } & N \\ \text { Artemisia indica } & 14 \\ \text { Urtica dioca } & 9 \\ \text { Commelina paludosa } & 7 \\ \text { Rubus ellipticus } & 5 \\ \text { Bidens pilosa } & 4 \\ \text { Cirsium arvense } & 3 \\ \text { Trifolium repens } & 3 \\ \text { Cassia occidentalis } & 3 \\ \text { Cassia tora } & 3\end{array}$

The following herbs were present at 2 sites:-

Geranium, Euphorbia heterophylla, Polygonum, Malastoma normale, Setaria, Solanum, Mentha, Maesa chisia, Salvia, Chenopodium, Fragaria.

The following herbs were found at 1 site:-

Species of Plantago, Impatiens, Crepis, Osbeckia nepalense, Hedychium, Clerodendrum, Amaranthus, Hyena, Drmaria diandra, Hypericum, Begonia, Anthraxon, Phyllanthus, Eleusine, Thalictrum, Dioscorea, Inula, Vicia, Ranunculus, Ageratum, Rosa, Galium, Imperata, Viola, Mimosa, Orhiza.

\section{Trees}

Grevillea robusta, Rhus wallichii, Inula, Castanopsis indica, Brassianopsis, Diospyros, Lyonia ovalifolia, Alnus nepalensis, Pinus roxburghii, Callistemon citrinus.

Ferns and Fern Allies

Polystichum, Asplenium, Thelypteris, Nephrolepis, Equisetum, Adiantum, Sellaginella, Glychenia, Cheilanthes, Pteridium aquilinum, Blechnum

Sites of suitable plant abundance for sampling were usually found on North facing slopes. This suggests that Eupatorium adenophorum may favor moist conditions or may not favor intense irradiation.

The index of exposure was taken as the sum of the angles between horizontal and visible horizon at 8 points of the compass. The index varied widely from $59-220$ and it is therefore suggested that exposure index has no significant effect on plant growth.

The $\mathrm{pH}$ of soils on which sites were situated ranged from $\mathrm{pH} 5.5-7$, with a mode of 6.5 . Not 
having information about soil $\mathrm{pH}$ in the surrounding environment we cannot conclude whether this is a favored $\mathrm{pH}$ range or not.

Soil texture appeared to have little effect on plant growth, as sites were situated on soils ranging for $50 \%$ and to $90 \%$ clay.

Little evidence of soil erosion was ever found on the sites themselves, though sometimes on adjacent areas where there was no dense vegetation, patches of bared soil were observed. It may therefore be suggested that Eupatorium adenophorum can act as a binding agent for the topsoil of disturbed areas.

Within sites, plant height varied from $60-150 \mathrm{~cm}$, average $103 \mathrm{~cm}$. galling activity of the fly is one factor which could affect plant height (Shrestha, 1979) though other variables such as soil fertility and insolation must be eradicated in a study focusing on this index.

The weed was found to have distinct growth habits:-

1) Individual erect stems with shorter plant height.

2) Clumped erect stems, from a common rhizome.

3) Stems trailing along the ground, especially on steep or rocky slopes.

The plant species most commonly found growing with Banmara were Artemisia (compositae), at 14 sites, and Urtica dioca (Urticaceae), at 9 sites. These plants were generally common throughout the study region.

The selection of site locations was inevitably based towards those situated adjacent to roads and paths. The most common land use was therefore verge, when the plant seemed to grow well, in keeping with its status as a colonizer of disturbed land. This was usually potential grazing land. The weed was also common in river valleys, gullies and ditches.

On the Trisuli to Gorkha area, no site work was undertaken west of Arugat, due to absence of the plant.

Data Analysis

1) To test if fly activity varies significantly between areas of discretely different rainfall.

Fly activity is measured by galls/site.

Trisuli to Gorkharainfall $1500-2000 \mathrm{~mm} / \mathrm{yr}$

Kathmandu Valley rainfall 1000-1500 mm/yr

Using t-test-variance not assumed equal: 


$$
s=\frac{\sum x^{2}-\frac{\left(\sum x\right)^{2}}{N}}{N-1}
$$
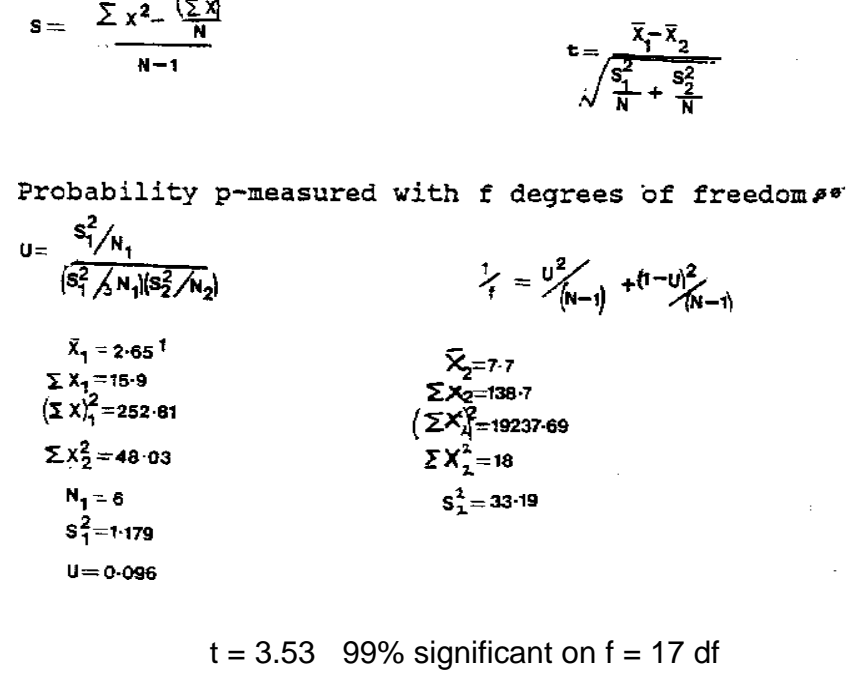

The measure of fly activity taken for this test was gall density i.e. the total number of galls per site given by the sum of galls in each quadrate. Thus the gall density data collected from rainfall band 1 (Trisuli to Gorkha) was compared with that collected from rainfall band 2 (Kathmandu Valley). Sites of equal plant density were not paired for the t-test since it was found that fly activity was not density dependent (see 2). The t-test showed that fly activity varied with rainfall at the $99 \%$ significance level. Fly activity was greater in the lower rainfall band.

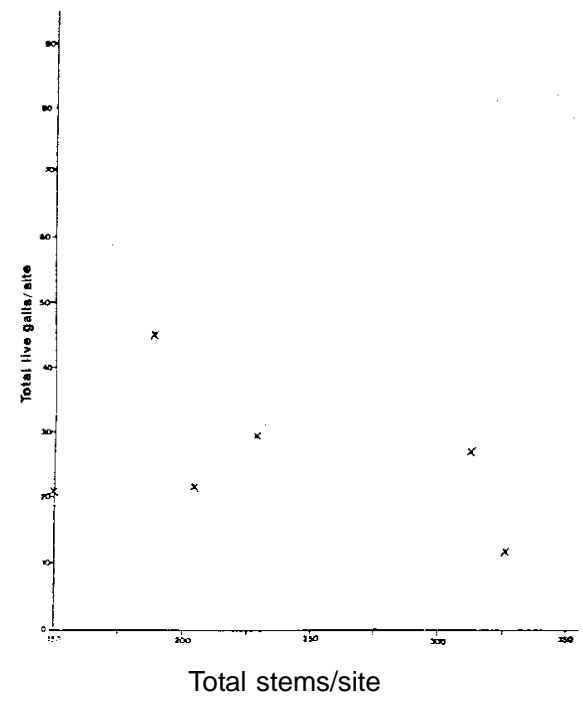

A. Graph of Total stems/site against Total live galls/site for the Trisuli - Gorkha trek 
To test for a correlation between gall density and plant density and hence potential regulation of $\mathrm{E}$. adenophorum by $\mathrm{P}$. utilis using correlation coefficient $-r$

$$
r=\frac{\sum x y-\frac{\sum x \leqslant y}{n}}{\sqrt{\left[\left(\xi x^{2}-\frac{(\xi x)^{2}}{n}\right)\left(\xi y^{2}-\frac{(\xi y)^{2}}{n}-\right)\right]}}
$$

Data from trek Trisuli - Gorkha

$$
\begin{aligned}
& n=6 \quad x=1412 \quad x^{2}=356754 \quad y=159 \quad y^{2}=4803 \quad x y=35977 \\
& r=-0.379 \\
& \text { non significant }
\end{aligned}
$$

A Graph of Total stems/site against Total live galls/site for the Kathmandu Valley

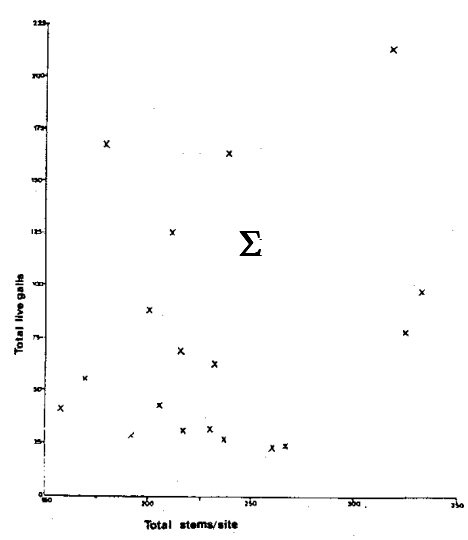

Correlation coefficient

Data from work in Kathmandu Valley

$$
\begin{aligned}
& n=18 \quad x=4262 \quad x^{2}=1034502 \quad y=1387 \quad y^{2}=163315 \quad x y=337978 \\
& r=0.252
\end{aligned}
$$

Non significant

In testing for potential regulation of the weed E. adenophorum by P. utilis, gall density was selected as a measure of fly activity. A positive correlation between gall density and plant density would be indicative of a density dependent relationship and hence the potential for regulation. Two separate graphs were drawn for the data collected from the trek between Trisuli and Gorkha and that from the Kathmandu Valley. This was done in order to eliminate the variable of rainfall which had been found to have a significant effect on fly activity. A correlation coefficient was calculated for both sets of data and found to be insignificant in each case P. utilis does not exhibit 
density dependence on $\mathrm{E}$. adenophorum and hence there is no potential for regulation.

B. Graph of Total flies (potential) site again Total stem/site Or Trisuli - Gorkha

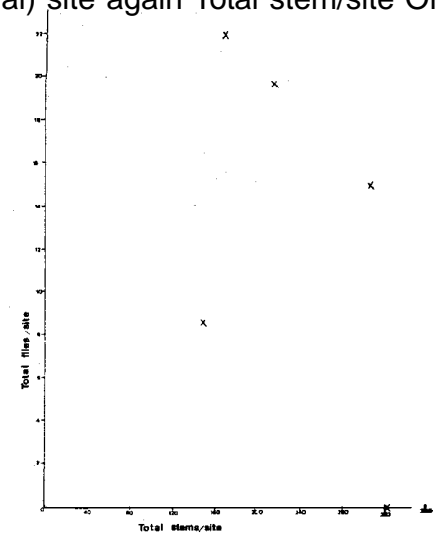

To test for a correlation between total flies/site and total stems/site and hence potential regulation of $E$ adenophorum $P$. utilis. Using correlation coefficient - $r$.

Data from Trek Trisuli - Gorkha

$\begin{array}{lcccc}N=5 & x=1203 & x^{2}=313074 & y=63.9 & y^{2}=1114.14 \quad x y=14220.36 \\ r=-.44 & \Sigma\end{array}$

Non significant

D. Graph of Total flies (potential) / site against Total stems for Kathmandu Valley

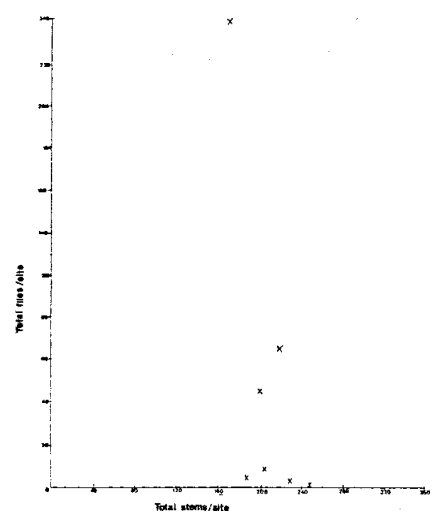

C.Correlation coefficient calculated from data collected in Kathmandu Valley.

Total stems $/$ site $=\mathrm{x}$ Total flies $/$ site $=\mathrm{y}$

$\mathrm{N}=7 \quad \mathrm{x}=1486 \quad \mathrm{x}^{2}=320216 \quad \mathrm{y}=349.7 \quad \mathrm{y}^{2}=55362.52 \quad \mathrm{xy} x=65995.13$

$r=-0.603$ Non significant 
A correlation coefficient between the total number of flies (potential per site and the total number of stems per site was calculated as a second method of testing for density dependence between gall fly and plant. The total no of flies per site was determined on the assumption that where a parasite emerged a fly formerly existed in the gall and hence the total no. of flies and parasites emerged from a site were summed to give total potential number of flies. This figure was divided by the number of galls selected for rearing through and multiplied by the total no. of live galls counted in the site to give the total potential no of flies in a site. Once again data from the trek Trisuli - Gorkha and from the Kathmandu Valley were treated separated to eliminate the significant variable of rainfall. Both correlation coefficients were non significant indicating that density dependence was not occurring and hence no potential regulation.

To test if parasite density varies significantly between zones of discretely different rainfall.

Parasite density measured by number of parasites/gall/site.

Using t-test-variance not assumed to be equal

$\begin{array}{ll}\bar{x}_{1}=0.0156 & \bar{x}_{2}=0.1185 \\ \sum x_{1}=0.78 & \sum x_{\cdot 2} \\ \sum x_{1}^{2}=0.2252 & \sum x_{2}^{2}\end{array}$

$\mathrm{n}=5 \quad \mathrm{n}=2$

$\mathrm{t}=0.047$ not significant on $7 \mathrm{df}$.

For this test, parasite density for each site was determined from the rearing through data and compared for the two zones by means of a t-test. The effect of rainfall on parasite density was not found to be significant.

A E.Graph of Total parasites/site against Total live galls/site

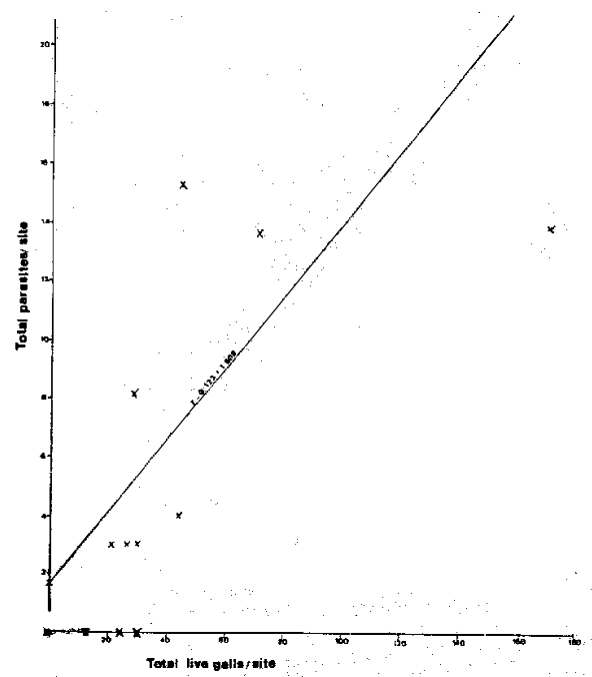


To test for a correlation between total no parasites/site and total no live galls per site and hence to demonstrate parasite density dependence using correlation coefficient $-r$. Data for two study areas pooled. Total galls $=x$ total parasites $=y$

$$
\begin{aligned}
& N=12 \quad x=585 \quad x^{2}=49667 \quad y=91026 \quad y^{2}=1531076 \quad x y=7053.33 \\
& r=0.61887 \text { on } 11 d f-95 \% \text { significant } \\
& \text { regression line } y=0.123+1.608
\end{aligned}
$$

A density dependent relationship between parasites and $\mathrm{P}$. utilis was tested in 2 ways a) by comparing the number of parasites per site with live galls/ site, a measure of fly activity and hence fly abundance $b$ ) by comparing the number of parasites per site with the total number of flies/site (determined as described in (3)).

The data from the trek between Trisuli and Gorkha and from the Kathmandu Valley were pooled since rainfall had previously been determined to have an insignificant effect on parasite density. The correlation coefficient was significant at the $95 \%$ level in the first case, (5a) indicating a density dependant relationship between parasites and gall flies.

The correlation coefficient for the graph of number of parasites per site against total flies per site was insignificant.

F. A graph of Total flies/Sites against total parasites/Sites

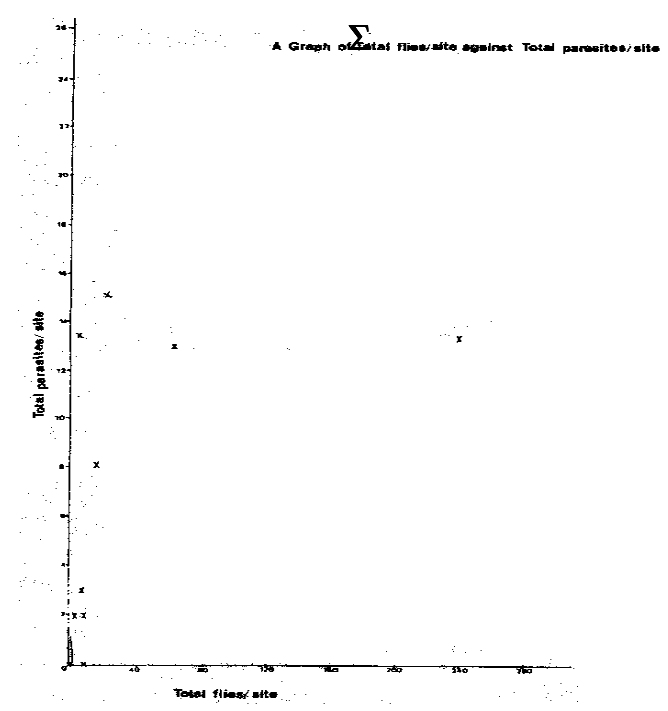

To test for a correlation between the no. of flies/site and no. of parasites/site using correlation coefficient $(r)$
$\mathrm{N}-12 \quad \mathrm{x}=413.58$
$x 2=171048.42$
$y=91.26$
y2 $=8328.4$
$x y=5746.2$
$r=0.437$ - non significant 


\section{Discussion}

\section{Control of E. adenophorum}

Graphs (2a), (2b), (3a) and (3b) and their statistical analysis (2) and (3) show no correlation between extent of galling and plant density, thus indicating there to be no potential for the control of E. adenophorum by P. utilis in Nepal. This result confirms field observations of the weed which was noted covering wide areas of land despite frequently heavy galling. The prevailing opinion in Nepal was that the colonization of woodland by E. adenophorum had continued unabated since the gall fly's introduction.

The findings of this study differ from those carried out in Hawaii (Hawaiian 1975) were control of the weed by the gall fly was highly successful in some areas. The difference in the regulatory activity of P. utilis in Nepal and Hawaii is supported by a comparison of the number of galls per stem in the two countries; the average for Hawaii is more than an order of magnitude greater than Nepal.

Since its importation into Nepal in 1967, the fly population should have built up to a maximal value: it is probable that even this maximum population present at any one time in Nepal is insufficient to adequately control the plant. Two reasons could account for this:-

\section{a) Cultural Practices}

In Nepal, mechanical measures are employed to curb the spread of Banmara onto agricultural land; the plant is also harvested for use as cattle bedding and green manure. Such continual cutting back of $\mathrm{E}$. adenophorum and concomitant destruction of live galls could reduce recruitment of flies into the next generation thus decreasing the gall fly's regulatory effect. However, the cutting back of Banmara is unlikely to be the sole reason for its reduced control by P. utilis, as only a very small percentage of the plant is affected by this technique.

\section{b) Seasonal variation in Nepal}

By comparison with the tropical hills of Hawaii, seasonal climate variation in Nepal is considerable. P. utilis and E. adenophorum may be uniquely adapted to the unfamiliar climatic variation encountered in Nepal. The gall fly may be more sensitive than the plant to one or many environmental factors, thus leading to an annual reduction of the total fly population and reducing its capacity to regulate the weed. The relative tolerance of Eupatorium in surviving severe environmental stress may be due, in part, to the presence of the amino acid, praline, in its leaves. Proline may protect cells against solution effects caused by dehydration during freezing. (Jha, pers comm.)

\section{Rainfall}

From statistical analysis (1), there is a correlation between rainfalls and galling, revealing that fly activity is higher in the lower rainfall band of 1000-1500 mm/yr than in the 1500-2000 $\mathrm{mm} / \mathrm{yr}$.

This effect of rainfall in $P$. utilis is as previously determined by work in Hawaii, where control of Eupatorium by $P$. utilis was considerably reduced in wetter areas. (Wilson et al 1985). However, the possibility cannot be dismissed that the greater fly activity in the lower rainfall 
band of Kathmandu Valley may be due to a difference in fly distribution between the 2 rainfall bands.

A population of 11,200 flies was released in the Kathmandu Valley by the entomology division, Khumaltar Agricultural Research Station; the population of P. utilis between Trisuli and Gorkha may not have attained the density of that in the Kathmandu Valley.

\section{Secondary Parasites}

Statistical analysis (4) showed that parasite density was not significantly affected by rainfall. The pooling of data from the 2 regions of differing rainfall was therefore justified in further calculations.

Graph (5a) of total parasites/ site against total live galls/site was found to be significant, indicating a density dependent response between secondary parasites and $P$. utilis secondary parasites and hence a possible cause of the fly's inability to control E. adenophorum.

For graph (5b) of number of parasites/site against number of flies/site, the correlation coefficient was not significant - parasite density was independent of $P$. utilis density. This discrepancy between the 2 methods of determinant parasite density dependence may be accounted for in that the latter correlation was base on the total number of flies as determined by the rearing through of gall contents. This process was hampered in some cases by excessively wet monsoon conditions.

\section{Other Methods of Control}

\section{a. Chemical}

Present investigations into the chemical control of $E$. adenophorum by herbicides reveal standard doses to be ineffective, but growth may be checked by double or triple doses. 'Round-up' (glycophosphate) proved to be most successful in herbicide trials carried out in Nepal. (Jha, pers com).

Studies of the herbicidal control of Eupatorium by George in Kerala, India, show that the nonhormone type herbicide gramaxane killed the weed in 3 days at a concentration of $1 \%$. The hormone derivative 2,4 Dichlorophenoxy acetic acid, at a concentration of $1.5 \%$ took by contrast 10-14 days to kill Eupatorium at the same rate of spray application.

Although it appears that a successful degree of control of Eupatorium may be achieved by use of some herbicides it is unlikely that this is a financially viable proposition in Nepal. The nature of the required dosage raises the question of the environmental safety of such a control method for Eupatorium.

\section{b. Cercospora eupatorii}

At a number of sites, a brown leaf spot fungus, Cercospora eupatorii was observed on the lower leaves of $E$. adenophorum. Toward the base of the stems, its lesions caused leaf fall and at times major defoliation. Dodd (1961) reports that adults of P. utilis have been found to carry the fungus spores and to capable of transmitting the disease.

The presence of Cercospora eupatorii at Bogate (site 6) and along the Trisuli Road (sites 8- 
11) had an extremely debilitating effect an Banmara, manifested by defoliation towards the stem base and dead leaves higher up. At all sites, the action of Cercospora eupatorii appeared to be a greater contribution to weed control than that of P. utilis.

\section{c. Grazing}

Banmara is generally unpalatable to all grazing animals as a fodder plant. Goats were observed grazing the weed where few other fodder plants were available; however this is so infrequent and on so small a scale that it cannot be considered a realistic control method for Banmara.

\section{d. Ethnobotany of Banmara}

Though banmara is considered weed and not suitable for other tree species to grow in the area where they grow, his species has a number of benefit as medicinal, fuel, compost etc mentioned else where.

\section{E. adenophorsum pest or asset?}

E. adenophorum cannot be considered only as a weed; it has a wide ecological impact, its effects ranging from the highly destructive to the beneficial.

\section{Banmara as a pest}

1) Prevention of forest regeneration

E. adenophorum colonization follows the pattern of human deforestation which is occurring at and alarming rate in Nepal, where wood is still the primary fuel source. Once established, Banmara prevents forest regeneration and hampers attempts at afforestation by its dense stands. The plant was found to be absent from undisturbed climax forest in Eastern Nepal.

2) Damage to agricultural and grazing land

Rice and maize compete successfully with Banmara; therefore the plant's invasion of such cereal fields does not occur. However, Banmara does become a problem in marginal rice growing areas. In such areas rice seeds are germinated indoors and the seedlings transplanted over a period of some 3 weeks, when the paddy-field temperature is an optimum value, E. adenophorum exerts its detrimental effects by shading paddy-fields immigration channels, causing a drop in water temperature which educes the period over which rice-seedling transplantation can take place from 3 weeks to 1 week.

Banmara was often seen invading marginal grazing lands; the plant is avoided by livestock due to its poor nutritional value and unpalatable nature, though our own observations showed that Banmara was grazed by goats if no alternative food source was present. Toxic effects of E. adenophorum have been noted in Australia where ingestion by horses leads to Numinbah disease, a condition which commences as oedema of the lungs followed by haemorrhage causing death.

3) Depletion of soil minerals

One of the major detrimental effects of Banmara is its high rate of soil mineral extraction: this 
problem is exacerbated when the plant is harvested and the nutrients not returned to the soil by rotting.

The nutritionally demanding nature of the species is shown by the following data: (Promod Kumar Jha, pers comm.)

$\begin{array}{ccc}\% & \text { Banmara free soil } & \text { Banmara invaded soil } \\ \mathrm{Ca} & 1.12 & 0.25 \\ \mathrm{Mg} & 1.00 & 0.50 \\ \mathrm{Fe} & 2.66 & 2.08 \\ \mathrm{Mn} & 0.05 & 0.03\end{array}$

The resultant loss in the carrying capacity of the land accounts in part for Banmara's high competitiveness and of soil regeneration.

Table 1. Nutritional composition of Eupatorium adenophorum show high carbon, nitrogen and potassium compare to other species (Shrestha Vaiday et al 2008)

\section{Banmara as an asset}

\section{1) Prevention of soil erosion}

Concomitant with the deforestation threatening Nepal's natural resources is soil erosion.

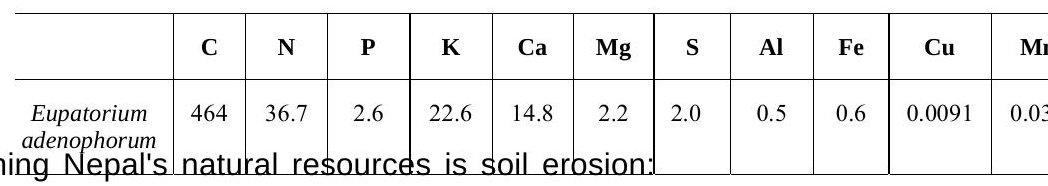
the soil is no longer bound by deep roots, enriched with leaf litter or protected from splash and rill erosion by the canopy. Although Banmara is a considerable hindrance in afforestation programmes, it is one of the few species which thrives on roadside cuttings and steep banks, establishing a humus layer on such slopes. It is thus important as a 'first line of defence' on these slopes.

In this capacity, however, it replaces grasses, which would colonize such niches in the absence of Banmara; the former are earlier replaceable with economically valuable fodder crops, as well as binding the topsoil more firmly due to their different rooting system.

\section{2) Village Uses}

Despite its status as an agricultural pest, Banmara is used in the following ways by village farmers: the nutrient rich foliar parts are rotted down for green manure in spring, particularly rewarding due to the high nutrient content of the plant; the leafy stems are harvested as cattle bedding in Autumn; the dry brittle stems are burnt as fuel in winter; this burning also renders a potash-rich fertilizer.

\section{3) Biogas Production}

Work at the Mycology Dept. of Tribhuvan University has shown E. adenophorum to be an 
excellent substrate for the production of biogas, of all 7 species of Eupatorium employed, it gives the highest yield $(8595 \mathrm{ml}$ gas $/ 20 \mathrm{~kg}$ dry $\mathrm{wt}$ ) using the degrading bacterium Methanobacillus. All members of the genus gave a higher yield than dung, which is a more commonly used substrate and better employed as fertilizer. This is of great potential importance since biogas production is being extensively developed for agricultural village communities in Nepal.

\section{4) A Potential source of Herbicides}

Eupatorium appears to possess allelopathic properties, and the presence of growth inhibiting factors has been recorded in all plant parts, the leaves being a particularly rich source of toxins. Inhibition of seed germination and linear growth of Zea and Amaranthus indicated that inhibition of leaf extracts was greater than that of stem samples, which was in turn greater that root extracts. Achmod and Nabi have isolated Ceryl alcohol and a steroid from foliar parts. However, Banmara has not yet been intensively screened for compounds with herbicidal properties (George 1968).

\section{5) Medicinal uses}

These include the consumption of an infusion of leaves to cure stomach pains, whilst a paste of the apical leaves and slaked lime is reputed to coagulate blood. Moni et al (1959) suggested that insect repelling oil may be extracted from the plant.

\section{6) Wildlife Sanctuary}

Banmara may provide shelter for wildlife including deer, jackals and porcupines. Eupatorium also harbors agricultural pests such as foxes.

\section{Future Perspectives}

In Central Nepal, all attempted control methods used on E. adenophorum have been unsuccessful. In this context, it may be more constructive to view the plant not solely as a pest, but rather to concentrate on the exploitation of its potential benefits. The major detrimental effects of Banmara are related to the depletion of soil minerals and the hampering of attempts of afforestation. This highlights the need for field trials to discover trees, fodder crops and nutrient replacing species which could successfully compete with, and grow up in Banmara stands. Such a situation would capitalize on Banmara's ability to prevent soil erosion during the vulnerable stages of seedling development. Further work on Banmara's commercial uses in biogas and herbicide production could prove rewarding.

However, the need for control of Eupatorium in certain circumstances cannot be overlooked; villages may be forced to bring marginal lands invaded by Banmara into cultivation. In view of the inadequacy of P. utilis as a control agent, the potential of the fungus Cercospora eupatorii as a means of control would be valuably further examined. 


\section{Acknowledgement}

The authors would like to thank Oxford University, Tribhuvan University, Nepal, The British Museum, The Royal Geographical Society, The British Ecological Society, Department of National Park and Wildlife Conservation, and British Embassy, Kathmandu for various supports. Thanks are due to all who have greatly extended cooperation in the data analysis and to who accompanied us in the remote Langtang area during the research expedition.

\section{Reference}

Dodd, A.P, (1953). Observation on the stem gall flies of Pamakani, Eupatorium glandulosum. Proceeding of Forestry.

George. K, (1968). Herbicide control of Eupatorium. Int Forester, 94:817-8.

Hawaiian Ent. Soc., 15(1):41-44

Haseler, W.H, (1966). The status of insects introduced for the biological control of weeds in Queenland. J.Ent. Soc. Queensland, 5:1-4

Hoy, J.M,: (1960). Establishment of Procecidochares utilis (Stone) on Eupatorium adenophorum (Sprengel) in New Zealand. N.Z.J. Sci., 3:200-2003

Kapoor, V.C. and Y.K.Malla, (1978). The infestation of the gall fruit fly, Procecidochares utilis (Stone) on Eupatorium adenophorum (Sprengel) in Kathmandu

Rao, V.P. M.A. Ghani, T. Sankara, K.C. Mathur, (1971). Crofton weed-Eupatorium adenophorum: tech. Communication, Common wealth Inst. Biological Control, Trinidad, 65:64

Shrestha, I.M. (1979). An ecological assessment of galling on the control of the weed Eupatorium adenophorum (Sprengel), Tribhuvan University, Master Thesis.

Shrestha Vaidya, G; K. Shrestha; B.R. Khadge; N. C. Johnson and H. Wallander (2008). Organic matter stimulates bacteria and arbuscular mycorrhizal fungi in Bauhinia purpurea and Leucaena diversifolia plantation on eroded slopes in Nepal. Restoration Ecology, UK, 16(1):78-87

Swaminathan, S. and A. Raman, (1981). On the morphology of the stem galls of Eupatorium adenophorum (Sprengel) and the natural enemies of Procecidochares utilis. Current Science, 50:294-295.

Wilson, W: M.Walisiewicz, S.Harvey, H.Gay and K.Shrestha (1985). The report of the Oxford University expedition to Nepal.

\section{Author's Address}

${ }^{1}$ Dr. Keshab Shrestha, ${ }^{2}$ Emma Wilson and ${ }^{2}$ Honer Gay

${ }^{1}$ Natural History Museum, Swayambhu, Kathmandu, Nepal

${ }^{2}$ Oxford University, U.K. 